\title{
EVALUATION OF Bacillus thuringinesis ALONE OR MIXTURE WITH AMINO ACID FOR CONTROLLING COTTON LEAFWORM , Spodoptera littoralis (Boisd.) \\ Abou Zeid ,N. A. ; $^{1}$ Aml,A.Abd-Allah ${ }^{2}$;E.S. Mansour ${ }^{2}$ and G.H. Ebaid ${ }^{1}$ 1- Cotton Insecticids Evalutione Research Department, plant Protection Research Institute, A.R.C., Dokki Giza, Egypt. \\ 2-Crop Pests Research Dept., Plant Protection Res. Institute, Agric. Res. Centre, Giza, Egypt
}

\begin{abstract}
Second instar larvae of Spodoptera. littoralis were fed on caster bean leaves treated with different concentrations of Dipel (Bacillus thuringiensis var. kurstaki). after 72 hours of treatment (estimated $L_{50}$ ) Regarding the $\mathrm{LT}_{50}$ values a negative relationship could be detected between the applied concentration of Dipel and $\mathrm{LT}_{50}$ value; i.e. the $\mathrm{LT}_{50}$ was shortened with the increase in Dipel concentration. The $\mathrm{LT}_{50}$ values being $14.17,8.81,5.99$ and 2.40 days for the used concentrations of $8,12,16$ and $20 \times 10^{4} \mathrm{I}$.U. The second instar S. littoralis larvae were fed on fresh caster bean leaves treated with different concentrations of Dipel $+05 \%$ Amino. , the corrected mortality percentages after 3 days increased by increasing concentration ranged from 40.00 to $90.00 \%$ at the concentrations of 8 to $28 \times 10^{4} \mathrm{I}$.U., the $\mathrm{LC}_{50}$ value was $11.31 \times 10^{4} \mathrm{I} . U$. for $S$. littoralis after 3 days., comparing the effects of the two treatments (Dipel and Dipel $+0.5 \%$ Amino) on the mortality percentages at same concentration used, Diple $+0.5 \%$ treatment led to increase the percentages of mortality in all concentrations used and thus led to decrease the value of $\mathrm{LC}_{50}$ from 17.14 to $11.31 \times 10^{4}$ S.U. and shortened also the values of $L_{50}$ from 14.7, 8.81 and 5.99 to $6.66,3.88$ and 2.18 days at concentration of 8,12 and $16 \times 10^{4}$ I.U. , respectively, The LC 50 of Diple $2 x+1 \%$ Amino Acid was $15.59 \times 10^{4}$ I.U. 72 hours post treatment, a negative relationship could be detected between the applied concentration of Dipel $+1 \%$ Amino and. the $\mathrm{LT}_{50}$ was shortened with the increase in treatments concentration. These values were $11.61,7.97,3.99,3.07$ and 1.72 days for the used concentrations of $8,12,16,20$ and $24 \times 10^{4}$ I.U. , respectively . LC 50 of Diple $2 x+1.5 \%$ Amino Acid was $16.06 \times 10^{4}$ I.U. after 3 days of treatment. and LT 50 values. were $14.12,6.73,3.13$ and 1.69 days at concentrations of $8,12,16$ and $20 \times$ $10^{4}$ I.U. , respectively.. The $\mathrm{LC}_{50}$ of Diple $2 \mathrm{x}+2.5 \%$ Amino Acid was was $16.62 \times 10^{4}$ I.U.. After3 days from treatment while the $\mathrm{LT}_{50}$ values were $11.18,6.56,4.15$ and 2.80 days at concentrations of $8,12,16$ and $20 \times 10^{4}$ I.U., respectively. , LC 50 value of Dipel $2 x+0.5 \%$ amino $\left(11.31 \times 10^{4}\right.$ I.U.) was the most effective one among all treatments ,also, led to shortened the values of $\operatorname{LT}_{50}(6.66,3.88$ and 2.18 days for the used concentrations of 8,12 and $16 \times 10^{4}$ I.U., respectively
\end{abstract}

Keywords: Bacillus thuringiensis var. kurstaki, Spodoptera. Littoralis, Amino Acids, mixture.

\section{INTRODUCTION}

Overuse of Chemical pesticides have caused considerable environmental problems and they have even threatened human health (Gill et al., 1992). The bioregional insecticide Bacillus thuringiensis is a useful alternative to chemical pesticides that has been developed for the control of 
certain insect pests. The biological insecticides based on $B$. thuringiensis have been valued for their environmental safety, their low development costs, and their specific activity against certain insect pests (Lambert and Peferoen, 1992).

Recently, microbial insecticides consider as a component of biological control techniques are developed and encouraged. They give good results against insect pests without polluting the environment (Amer et al., 2012). Besides, giving low toxicity to non-target animals and humans (Aranda et al., 1996). The most abundant and successful microorganism used as effective bioinsecticide was $B$. thuringiensis (Cartton, 1988; De Maagd et al., 2001 and Ibrahim \& Omar, 2005). The basis of $B$. thuringiensis insecticidal activity comes from the $\delta$-endotoxin formed during sporulation and is also toxic to insect larvae belong to order Lepidoptera (El- Husseini et al., 2012). B. thuringiensis infected larvae showed significant higher percentages of cellular apoptosis at 12 an 24h post-infection compared to control ones. These data may indicate that $B$. thuringiensis infection induced oxidative stress and apoptosis proceeding cellular damage. (Ashraf (2013). Also,, B. thuringiensis Induces Cellular Stress in the Mosquito Vector,Culex pipiens, Prior to Death.

(Treshow, 1970; El- Naggar, 1998; Mesbah et al., 2000; El- Naggar, 2009 and Magdoff et al., 2000) indicated farming practices that cause nutrition in balance can lower pest resistance.

Amino acids compositions in plant sap play critical role in determining susceptibility to sap sucking pests (Tsumuki et al., 1987). Rice plants with less asparagine content show resistance against brown planthopper (Sogawa and Pathak 1970). Resistant lines of oats and barley contain less quantity of asparagine and higher amounts of glutamic acid (Weibul et al.,1987). Resistance lines of oats and barley contain less quantity of asparagine and higher amounts of glutamic acid (Weibull et al.,1987; Hedin et al., 1990). Aspartic acid metabolic pathway controls the biosynthesis of amino acids asparagine, aspartic acid and glutamic acid in plants. Aspartic acid is the starting compound for two main pathways, one leads to the synthesis of asparagine and other to aspartate-derived amino acids viz., lysine, threonine, methionine and isoleucine (Azevedo et al., 1997). The present study aimed to evaluate the impact of $B$. thuringiensis alone or in mixtures with Amino acids to against cotton leaf worm, Spodoptera littoralis .

\section{MATERIALS NAD METHODS}

\section{1-Rearing of S. littoralis}

A laboratory stock culture of $S$. littoralis started with larvae collected from the field and maintained under constant conditions of $27 \pm 3{ }^{\circ} \mathrm{C} \& 65 \pm$ $5 \%$ R.H. according to the methods recorded by Mansour (2001) .

2-Tested compounds :

a- Dipe $2 \times 6.4 \%$ a selective bacterial insecticide containing $32 \times 10^{6}$ I.U. of $B$. thuringiensis var. kurstaki / gm. of product. 
b-Canada Amino: The main components are:Nitrogen 5\% -Phosphorous 3\% - Potassium 4\% -Iron 1.5\% - Zinc 1.1\% - Manganese 1.1\% - Humic acid 10\% -amino acids $10 \%$-active fulvic acid $2.5 \%$.

3- Treatments:

Five experimental treatments were carried out as follows:

a- Bioinsecticidal treatments:

Weights of $2.5,3.75,5.00,6.25,7.5$ and $8.75 \mathrm{gm}$. of Dipel $2 \mathrm{x}$ were diluted in water to obtain a constant volume of $200 \mathrm{ml}$ (total volume), to represent the concentrations of $8,12,16,20,24$ and $28 \times 10^{4}$ I.U., respectively.

b- Bioinsecticide + different concentrations of Amino Acids:

A volume of $7.5,15,22.5$, and $37.5 \mathrm{ml}$ of Canada Amino were diluted in water to obtain constant volume of 1.5 liter (total volume) of to give solution of concentrations of $0.5,1,1.5$ and $2.5 \%$. For each prepared solution six concentrations of $8,12,16,20,24$ and $28 \times 10^{4}$ I.U. of Dipel $2 x$ were prepared as previously described.

The following procedures were applied:

For each concentration of any tested treatment, three replicates, each of ten second instar larvae, placed in a jar for rearing to feed on the caster bean leaves treated with the bioinsecticide or with bioinsecticide + different concentrations of amino. Mortality rates were recorded daily. Larvae that survived after treatment were transferred to other jars containing untreated caster bean leaves. Before exposing the larvae to treated food, they were starved for 4 hours in order to obtain rapid simultaneous ingestion of the contaminated food.Control test was conducted by dipping clean caster bean leaves in water, left to dry and then offered to the experimental larvae.The experiments were carried out under laboratory conditions of $27 \pm 3{ }^{\circ} \mathrm{C}$ and 65 $\pm 5 \%$ R.H. The castor-bean leaves were dipped for one minute in each of the used concentrations, and then treated leaves were left for air dryness and offered to the tested larvae.

Statistical analysis:

The effectiveness of the different treatments were expressed in term of $L_{50}$ values at 95 fiducially limits slopes of regression lines were represented. Statistical analysis of the obtained data was made based on the analysis of variance and liner regression analysis (Finney, 1971 and slide write program). In addition, polynomial regression procedure in COSTAT program was done.

\section{RESULTS AND DISCUSSION}

\section{I- Bioinsecticide (Dipel $2 x$ ) treatments:}

The daily corrected mortality percentages resulting from the treatment of $2^{\text {nd }}$ instar larvae of $S$. littoralis are shown in Table (1). Larval mortality percentages, 30 days post treatment were 63.33, 73.33, 76.67, 80.00, 83.00 and 83.33 \%at concentrations of $8,12,16,20,24$ and $28 \times 10^{4}$ I.U.., respectively. The percentages mortality after 72 hours of treatment (estimated $\mathrm{LC}_{50}$ ) ranged from 36.67 to $63.33 \%$ at concentrations of $8 \times 10^{4}$ to $28 \times 10^{4} \mathrm{I} . \mathrm{U}$ (fig 1 ) It is evident from Table (1) that the percentages mortality 
increased by increasing the concentration. The $L^{2} C_{50}$ value was $17.4 \times 10^{4}$ I.U. 72 hours post treatment (Table, 2 and Fig., 1). These results are in agreement with

The increased mortality percentages by increasing the concentrations of Dipel 2x agree with those previously reported by: Kares et al., (1992) on larvae of the cabbage worm Artogeia rapae when testeing Bactospeine; Badawy (2000) when he tested Dipel 2x. Ecotech bio and MVP ${ }_{11}$ against $S$. littoralis and the potato tuber moth Phthorimaea operculella; where also Ecotech bio and $\mathrm{MVP}_{11}$ were more effective than Dipel $2 \mathrm{x}$ against the second and fourth larval instars of S. littoralis, El-Khawas (2000) on the olive leaf moth Palpita unionalis larvae by using the bioinsecticide Xentari. Atalla et al.,(2001) on the three insect pests, S. littoralis, the black cutworm Agrotis ipsilon and corn stalk borer $S$. cretica when evaluating the effect of Agerin bioinsecticide.

Regarding the $L T_{50}$ values (Tables 3 ) and (Figs. 7) a negative relationship could be detected between the applied concentration of Dipel and $\mathrm{LT}_{50}$ value; i.e. the $\mathrm{LT}_{50}$ was shortened with the increase in Dipel concentration in larvae pests. The $\mathrm{LT}_{50}$ values being 14.7, 8.81,5.99 and 2.40 days for the used concentrations of $8,12,16$ and $20 \times 10^{4}$ I.U. These results are in agreement with those of Moawad et al., (1982 / 1983) tested Bactospine and Diple powders on larvae of Earias insulana; Kares et al., (1992) studied the efficacy of Bactospine on A. rapae larvae and Kares et al., (2002) tested the bioinsecticide Delfin against larvae of $O$. nubilalis.

\section{II- Bioinsecticide (Dipel 2x) + $05 \%$ amino acid}

The larval daily mortality of $S$. littoralis treated with different concentrations of Dipel $+05 \%$ amino are shown in Table (1), the corrected mortality percentages after 3 days increased by increasing concentration and ranged from 40.00 to $90.00 \%$ at the concentrations of 8 to $28 \times 10^{4}$ I.U. Whereas, as shown in Fig. (2), the $L^{2} C_{50}$ value was $11.31 \times 10^{4} \mathrm{I} . \mathrm{U}$. for $S$. littoralis after 3 days.

Also by regarding the $\mathrm{LT}_{50}$ values (Table 3 and Fig. 8) a negative relationship could be detected between the applied concentration of Dipel + $0.5 \%$ amino acid and $\mathrm{LT}_{50}$ value; i.e. the $\mathrm{LT}_{50}$ was shortened with the increase in treatments concentration. These values were 6.66, 3.88 and 2.18 days for the used concentrations of 8,12 and $16 \times 10^{4}$ I.U., respectively (Table 3).

By comparing the effects of the two treatments (Dipel and Dipel $+0.5 \%$ amino) on the mortality percentages at same concentration used, Diple +0.5 $\%$ treatment led to increase the percentages of mortality in all concentrations used and thus led to decrease the value of $\mathrm{LC}_{50}$ from 17.14 to $11.31 \times 10^{4}$ I.U. and shortened also the values of $\mathrm{LT}_{50}$ from $14.7,8.81$ and 5.99 to $6.66,3.88$ and 2.18 days at concentration of 8,12 and $16 \times 10^{4}$ I.U., respectively. 
Table (1): Corrected mortality percentages for second instar larvae of $S$. littoralis fed on caster bean treated with Dipel $2 x$ and its mixtures.

\begin{tabular}{|c|c|c|c|c|c|c|c|c|}
\hline \multirow[b]{2}{*}{ Treatments } & \multirow{2}{*}{$\begin{array}{c}\text { Concentrat } \\
\text { ion I } \\
\text {. U. }\end{array}$} & \multicolumn{7}{|c|}{$\%$ cumulative mortality after days of treatments } \\
\hline & & 3 & 8 & 12 & 16 & 23 & 26 & 30.00 \\
\hline \multirow{7}{*}{ Dipel } & 0 & 0.00 & 0.00 & 3.33 & 3.33 & 6.67 & 6.67 & 10.00 \\
\hline & $8 \times 10^{4}$ & 36.67 & 43.33 & 43.33 & 46.67 & 53.33 & 50.00 & 63.33 \\
\hline & $12 \times 10^{4}$ & 40.00 & 40.67 & 46.67 & 53.33 & 63.33 & 66.67 & 73.33 \\
\hline & $16 \times 10^{4}$ & 46.67 & 50.00 & 53.33 & 56.67 & 70.00 & 73.33 & 76.67 \\
\hline & $20 \times 10^{4}$ & 53.33 & 63.33 & 70.00 & 70.00 & 73.33 & 76.67 & 8.000 \\
\hline & $24 \times 10^{4}$ & 56.67 & 66.67 & 73.33 & 76.67 & 76.67 & 76.67 & 83.00 \\
\hline & $28 \times 10^{4}$ & 63.33 & 66.67 & 73.33 & 76.67 & 80.00 & 83.33 & 83.33 \\
\hline \multirow{7}{*}{$\begin{array}{c}\text { Dipel }+0.5 \% \\
\text { amino }\end{array}$} & 0 & 1.67 & 3.33 & 6.67 & 6.67 & 10.00 & 10.00 & 10.00 \\
\hline & $8 \times 10^{4}$ & 40.00 & 53.33 & 56.67 & 60.00 & 63.33 & 70.00 & 73.33 \\
\hline & $12 \times 10^{4}$ & 50.00 & 56.67 & 60.00 & 63.33 & 66.67 & 73.33 & 76.67 \\
\hline & $16 \times 10^{4}$ & 56.67 & 60 & 63.33 & 66.67 & 70.00 & 73.33 & 80.00 \\
\hline & $20 \times 10^{4}$ & 76.67 & 76.67 & 80.00 & 83.33 & 86.67 & 90.00 & 93.33 \\
\hline & $24 \times 10^{4}$ & 83.33 & 86.67 & 90.00 & 93.33 & 96.67 & 100 & \\
\hline & $28 \times 10^{4}$ & 90 & 93.33 & 96.67 & 100 & & & \\
\hline \multirow{7}{*}{$\begin{array}{l}\text { Dipel + } 1 \\
\% \text { amino }\end{array}$} & 0 & 1.67 & 3.33 & 6.67 & 6.67 & 10.00 & 10.00 & 10.00 \\
\hline & $8 \times 10^{4}$ & 43.33 & 43.33 & 45.67 & 50.00 & 53.33 & 60.00 & 63.33 \\
\hline & $12 \times 10^{4}$ & 43.33 & 43.33 & 50.00 & 56.67 & 63.33 & 70.00 & 73.33 \\
\hline & $16 \times 10^{4}$ & 50.00 & 53.33 & 63.33 & 66.67 & 73.33 & 73.33 & 76.67 \\
\hline & $20 \times 10^{4}$ & 53.33 & 56.67 & 66.67 & 70.00 & 73.33 & 76.67 & 80.00 \\
\hline & $24 \times 10^{4}$ & 56.67 & 63.33 & 73.33 & 73.33 & 73.33 & 76.67 & 80.00 \\
\hline & $28 \times 10^{4}$ & 63.33 & 66.67 & 70.00 & 73.00 & 76.67 & 80.00 & 83.33 \\
\hline \multirow{7}{*}{$\begin{array}{c}\text { Dipel + } 1.5 \\
\% \text { amino }\end{array}$} & 0 & 0.00 & 0.00 & 3.33 & 3.33 & 6.67 & 6.67 & 10.00 \\
\hline & $8 \times 10^{4}$ & 30.00 & 40.00 & 50.00 & 53.33 & 56.67 & 56.67 & 60.00 \\
\hline & $12 \times 10^{4}$ & 36.67 & 50.00 & 63.33 & 66.67 & 66.67 & 70.00 & 70.00 \\
\hline & $16 \times 10^{4}$ & 50.00 & 60.00 & 66.67 & 70.00 & 73.33 & 73.33 & 76.67 \\
\hline & $20 \times 10^{4}$ & 56.67 & 66.67 & 70.00 & 73.33 & 76.67 & 76.67 & 80.00 \\
\hline & $24 \times 10^{4}$ & 63.33 & 70.00 & 73.33 & 76.67 & 80.00 & 83.33 & 83.33 \\
\hline & $28 \times 10^{4}$ & 70.00 & 73.33 & 76.67 & 80.00 & 83.33 & 83.33 & 86.67 \\
\hline \multirow{7}{*}{$\begin{array}{c}\text { Dipel + } 2.5 \\
\text { \%amino }\end{array}$} & 0 & 0.00 & 0.00 & 3.33 & 3.33 & 6.67 & 6.67 & 10.00 \\
\hline & $8 \times 10^{4}$ & 26.67 & 43.33 & 50.00 & 53.33 & 66.67 & 66.67 & 70.00 \\
\hline & $12 \times 10^{4}$ & 43.33 & 50.00 & 53.33 & 60.00 & 66.67 & 70.00 & 73.33 \\
\hline & $16 \times 10^{4}$ & 50.00 & 53.33 & 60.00 & 66.67 & 70.00 & 73.33 & 76.67 \\
\hline & $20 \times 10^{4}$ & 53.33 & 60.00 & 66.67 & 70.00 & 73.33 & 76.67 & 80.00 \\
\hline & $24 \times 10^{4}$ & & 66.67 & 70.00 & 73.33 & 76.67 & 80.00 & 83.33 \\
\hline & $28 \times 10^{4}$ & 66.67 & 70.00 & 73.33 & 76.67 & 80.00 & 83.33 & 90.00 \\
\hline
\end{tabular}

\section{Diple2x + 1\% Amino Acid}

The daily corrected mortality percentages resulting from the treatment of $2^{\text {nd }}$ instar larvae of $S$. littoralis are shown in Table (1). Larval mortality percentages, 30 days post treatment were 63.00, 73.33, 76.67, $80.00,80.00$ and $83.33 \%$ at concentrations of $8,12,16,20,24$ and $28 \times 10^{4}$ I.U., respectively. The percent mortality percentages after 72 hours of treatment (estimated $\mathrm{LC}_{50}$ ) ranged from 43.33 to $63.33 \%$ at concentrations of 8 to $28 \times$ 
$10^{4}$ I.U . it is evident from Table (1) that the percent mortality increased as result of increasing the concentration. The $L C_{50}$ value was $15.59 \times 10^{4}$ I.U. 72 hours post treatment (Table, 2 and Fig., 3 ).

Also by regarding the $L_{50}$ values (Table 3 and Fig. 9) a negative relationship could be detected between the applied concentration of Dipel + $1 \%$ amino and $\mathrm{LT}_{50}$ value; i.e. the $\mathrm{LT}_{50}$ was shortened with the increase in treatments concentration. These values were 11.61,7.97, 3.99, 3.07 and 1.72 days for the used concentrations of $8,12,16,20$ and $24 \times 10^{4}$ I.U. , respectively .

Table ( 2): Comparative toxicity of second instar larvae of S. littoralis treated with different concentrations of bioinsecticide (Dipel) and amino acid

\begin{tabular}{|l|c|c|c|c|}
\hline Treatments & $\begin{array}{c}\text { Day after } \\
\text { treatments }\end{array}$ & LC 50 & Slope & $\begin{array}{c}\text { Confidence limits at } \\
\text { Po. 0.5 of LC 50 }\end{array}$ \\
\hline Dipel 2x & 3 & $17.14 \times 10^{4}$ & $1.42 \pm 0.2845$ & $14.39 \times 10^{4}: 20.63 \times 10^{4}$ \\
\hline Dipel 2x+0.5\% amino & 3 & $11.31 \times 10^{4}$ & $2.81 \pm 03058$ & $9.90 \times 10^{4}: 12.52 \times 10^{4}$ \\
\hline Dipel2x+1\% amino & 3 & $15.59 \times 10^{4}$ & $1.91 \pm 0.2893$ & $13.58 \times 10^{4}: 17.67 \times 10^{4}$ \\
\hline Dipel 2x+1.5\% amino & 3 & $16.06 \times 10^{4}$ & $1.97 \pm 0.5302$ & $12.21 \times 10^{4}: 20.52 \times 10^{4}$ \\
\hline Dipel 2x+2.5\% amino & 3 & $16.62 \times 10^{4}$ & $1.78 \pm 0.5265$ & $12.33 \times 10^{4}: 22.32 \times 10^{4}$ \\
\hline Amino & 3 & $11.20 \%$ & $1.57 \pm 0.3502$ & $6.34 \%: 45.92 \%$ \\
\hline
\end{tabular}

V Diple $2 x+1.5 \%$ amino acid

After 3 days of treatment, the corrected mortality percentages were 30.00 , $36.67,50.00,56.67,63.33$ and $70.00 \%$ at concentration of 8, 12, 16, 20, 24 and $28 \times 10^{4}$ I.U ,respectively (Table, 1). The LC50 value was $16.06 \times 10^{4}$ I.U. (Table, 2 and Fig.,4).

$\mathrm{LT}_{50}$ values (Table, 3 and Fig.,10) indicated a negative relationship between the applied concentrations of Dipel $+1.5 \%$ amino and $\mathrm{LT}_{50}$ values. These values were $14.12,6.73,3.13$ and 1.69 days at concentrations of $8,12,16$ and $20 \times 10^{4} \mathrm{I} . U$. , respectively. The same results were recorded by Ebaid (2001), when carrying out laboratory studies to evaluate the effect of Consult on larvae of S. cretica; ElKhawas (2000) when evaluating the effect of Consult on A. ipsilon larvae and Mansour (2001) who estimated the effect of Mimic on S. littoralis larvae.

VI Diple $2 x+2.5 \%$ amino acid

After3 days from treatment, the mortality percentages ranged from 26.67 to $66.67 \%$ by using concentration ranging from 8 to $28 \times 10^{4}$ I.U., respectively. Data presented in Table (1) revealed that the mortality percentages increased by increasing the tested concentrations of the bioinsecticide Dipel. However, as shown in Table (2) and Fig. (5) , the $\mathrm{LC}_{50}$ value was $16.62 \times 10^{4} \mathrm{I}$.U.. while the $\mathrm{LT}_{50}$ values were $11.18,6.56,4.15$ and 2.80 days at concentrations of $8,12,16$ and 20 $\times 10^{4}$ I.U., respectively (Table, 3 and Fig., 11). These values indicated a negative relationship between applied concentrations of Dipel and $\mathrm{LT}_{50}$ values.

Results agreed with finding of Badawy (2000) when he tested Dipel 2x, Ecotech bio and $\mathrm{MVP}_{11}$ against $S$. littoralis and the potato tuber moth $P$. operculella where also Ecotech bio and $\mathrm{MVP}_{11}$ were more effective than Dipel $2 x$ against the second and fourth instar larval of S. littoralis ; El-Khawas (2000) on the olive leaf moth Palpita unionalis larvae by using the bioinsecticide Xentari; Atalla et al., (2001) on the three insect pests, S. littoralis , Agrotis ipsilon and Sesamia cretica 
when evaluating the effect of Agerin bioinsecticide; Ebaid (2001) on larvae of $O$. nubilalis by studied the effect of Delfin bioinsecticide.

Table (3): Comparative mortality time values of second instar $S$. littoralis larvae fed on caster bean treated with different concentrations of Dipel and amino acid.

\begin{tabular}{|c|c|c|c|c|}
\hline Treatments & concentration & $\begin{array}{l}\mathrm{LT}_{50} \\
\text { days }\end{array}$ & Slope & $\begin{array}{l}\text { Confidence limits } \\
\text { at Po } 0.5 \text { of } L T_{50}\end{array}$ \\
\hline \multirow{4}{*}{ Dipel 2x } & $8 \times 10^{4}$ & 14.7 & $0.64 \pm 0.1488$ & $9.78: 20.92$ \\
\hline & $12 \times 10^{4}$ & 8.81 & $0.86 \pm 0.1498$ & $6.08: 11.42$ \\
\hline & $16 \times 10^{4}$ & 5.99 & $0.808 \pm 0.149$ & $3.42: 8.25$ \\
\hline & $20 \times 10^{4}$ & 2.4 & $0.696 \pm 0.151$ & $0.64: 4.26$ \\
\hline \multirow{3}{*}{$\begin{array}{l}\text { Dipel2x } \\
+0.5 \% \text { amino }\end{array}$} & $8 \times 10^{4}$ & 6.66 & $0.8028 \pm 0.1491$ & $3.97: 9.05$ \\
\hline & $12 \times 10^{4}$ & 3.88 & $0.6647 \pm 0.1488$ & $1.36: 6.19$ \\
\hline & $16 \times 10^{4}$ & 2.18 & $0.5666 \pm 0.1496$ & $0.30: 4.35$ \\
\hline \multirow{5}{*}{$\begin{array}{l}\text { Dipel2x } \\
+1 \% \text { amino }\end{array}$} & $8 \times 10^{4}$ & 11.61 & $1.91 \pm 0.2893$ & $6.08: 18.77$ \\
\hline & $12 \times 10^{4}$ & 7.97 & $0.49 \pm 0.1472$ & $5.13: 10.59$ \\
\hline & $16 \times 10^{4}$ & 3.99 & $0.80 \pm 0.1491$ & $1.73: 6.05$ \\
\hline & $20 \times 10^{4}$ & 3.07 & $0.76 \pm 1496$ & $1.13: 4.97$ \\
\hline & $24 \times 10^{4}$ & 1.72 & $0.63 \pm 0.1518$ & $0.26: 3.51$ \\
\hline \multirow{4}{*}{$\begin{array}{l}\text { Dipel } 2 x \\
+1.5 \% \text { amino }\end{array}$} & $8 \times 10^{4}$ & 14.12 & $0.78 \pm 0.1505$ & $10.52: 19.12$ \\
\hline & $12 \times 10^{4}$ & 6.73 & $0.90 \pm 0.1500$ & $4.35: 8.88$ \\
\hline & $16 \times 10^{4}$ & 3.13 & $0.71 \pm 0.1501$ & $1.07: 5.13$ \\
\hline & $20 \times 10^{4}$ & 1.69 & $0.64 \pm 0.1521$ & $0.27: 3.44$ \\
\hline \multirow{4}{*}{$\begin{array}{l}\text { Dipel } 2 x \\
+2.5 \% \text { amino }\end{array}$} & $8 \times 10^{4}$ & 11.18 & $1.15 \pm 0.1544$ & $8.97: 13.53$ \\
\hline & $12 \times 10^{4}$ & 6.56 & $0.79 \pm 0.1489$ & $3.82: 8.98$ \\
\hline & $16 \times 10^{4}$ & 4.15 & $0.73 \pm 0.1492$ & $1.76: 6.32$ \\
\hline & $20 \times 10^{4}$ & 2.80 & $0.73 \pm 0.1507$ & $0.91: 4.69$ \\
\hline
\end{tabular}

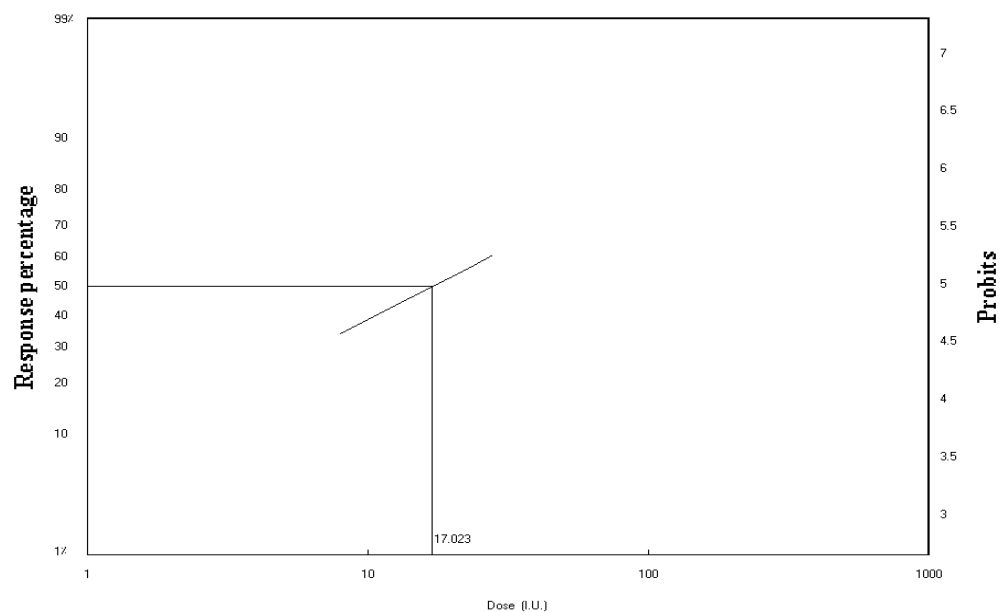

Fig. (1): Log concentration probit lines showing response of second instar larvae of $S$. littoralis treated with Dipel $2 x$ (computed from 72 hours mortality data. 
Abou Zeid ,N. A. et al.

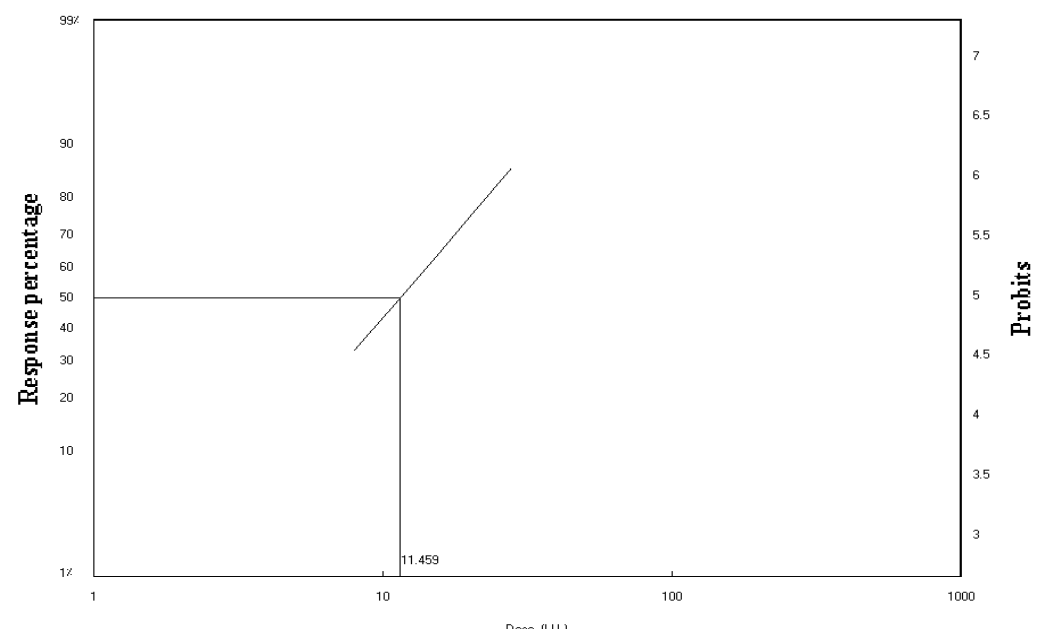

Fig. (2): Log concentration probit lines showing response of second instar larvae of $S$. littoralis treated with Dipel $2 x+0.5 \%$ amino (computed from $\mathbf{7 2}$ hours mortality data.

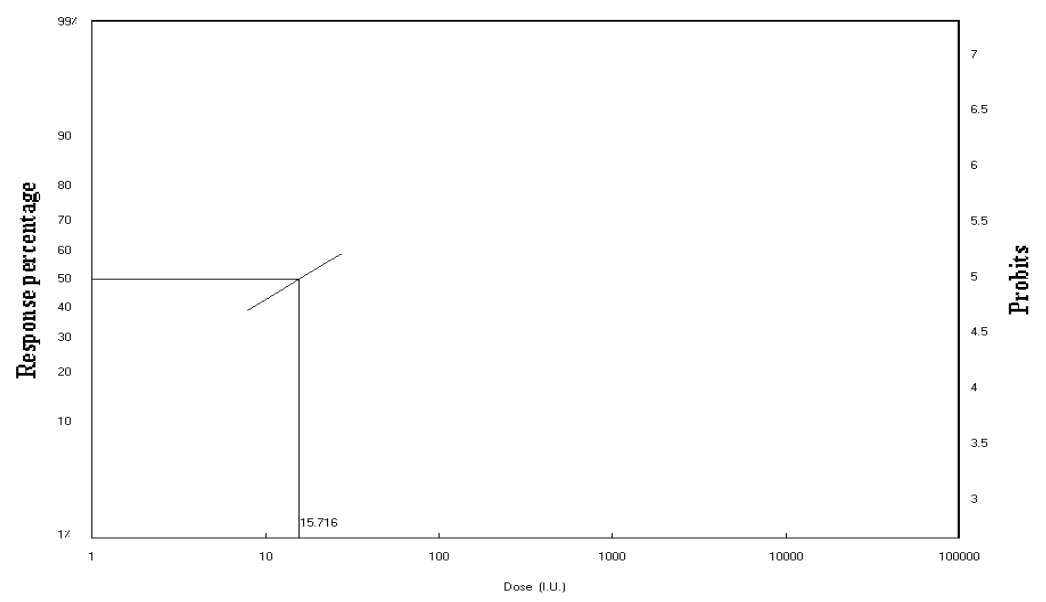

Fig. (3): Log concentration probit lines showing response of second instar larvae of $S$. littoralis treated with Dipel $2 x+1 \%$ amino (computed from $\mathbf{7 2}$ hours mortality data. 


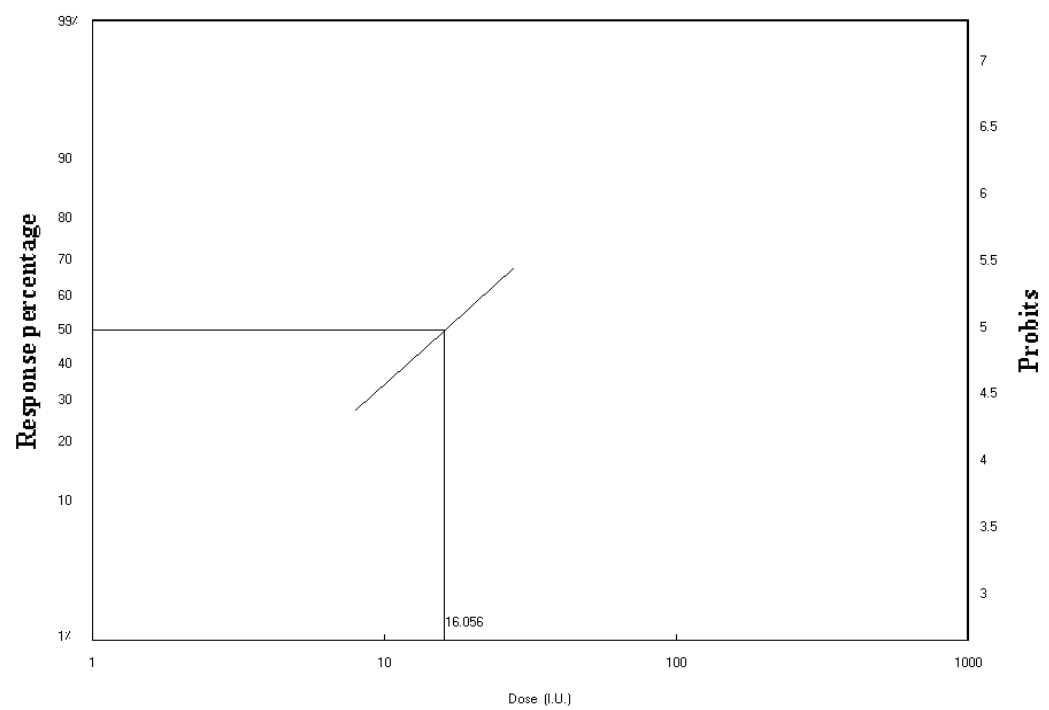

Fig. (4): Log concentration probit lines showing response of second instar larvae of $S$. littoralis treated with Diple $2 x+1.5$ amino (computed from $\mathbf{7 2}$ hours mortality data.

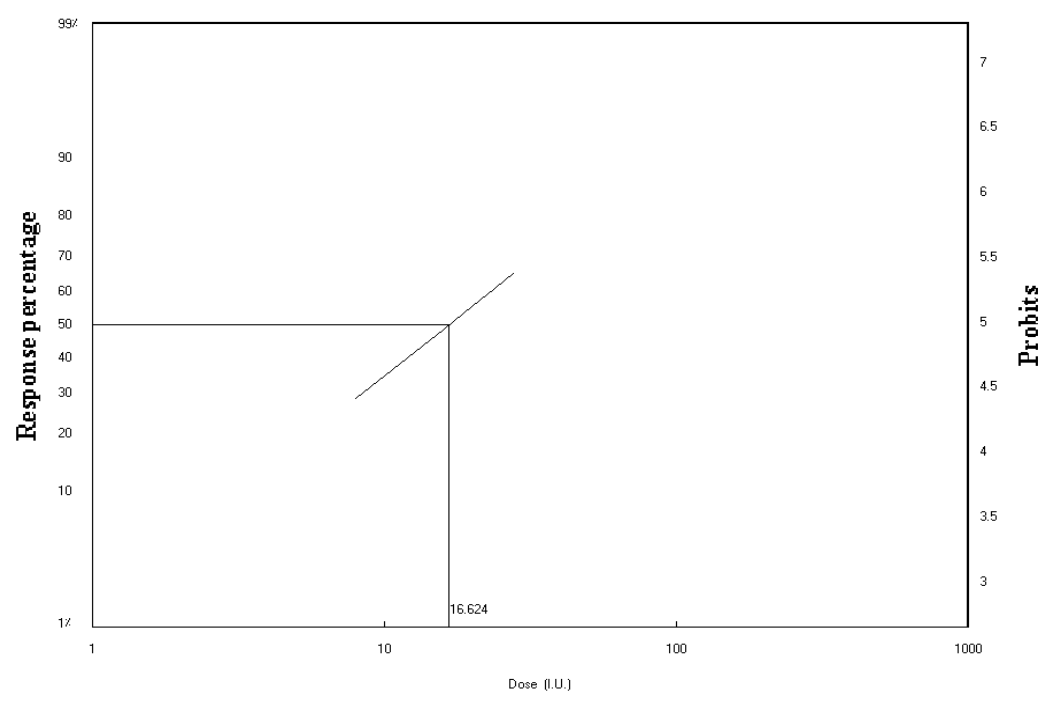

Fig. (5): Log concentration probit lines showing response of second instar larvae of $S$. littoralis treated with Diple2x $+2.5 \%$ amino (computed from 72 hours mortality data. 
Abou Zeid ,N. A. et al.

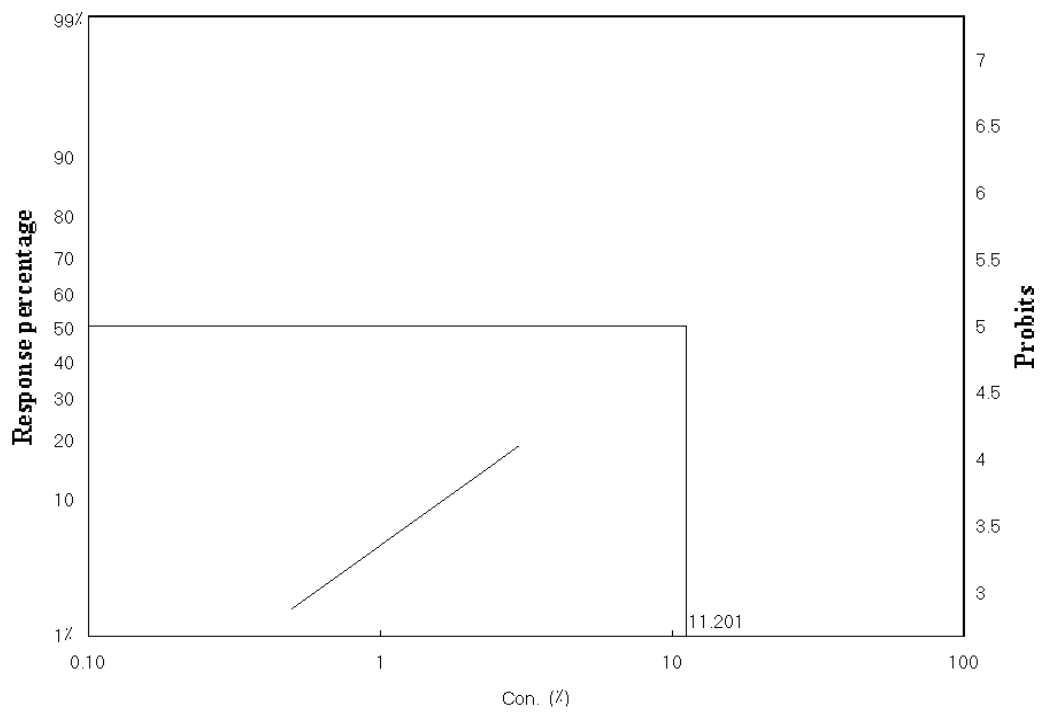

Fig. (6): Log concentration probit lines showing response of second instar larvae of $S$. littoralis treated with different concentration of amino acid.

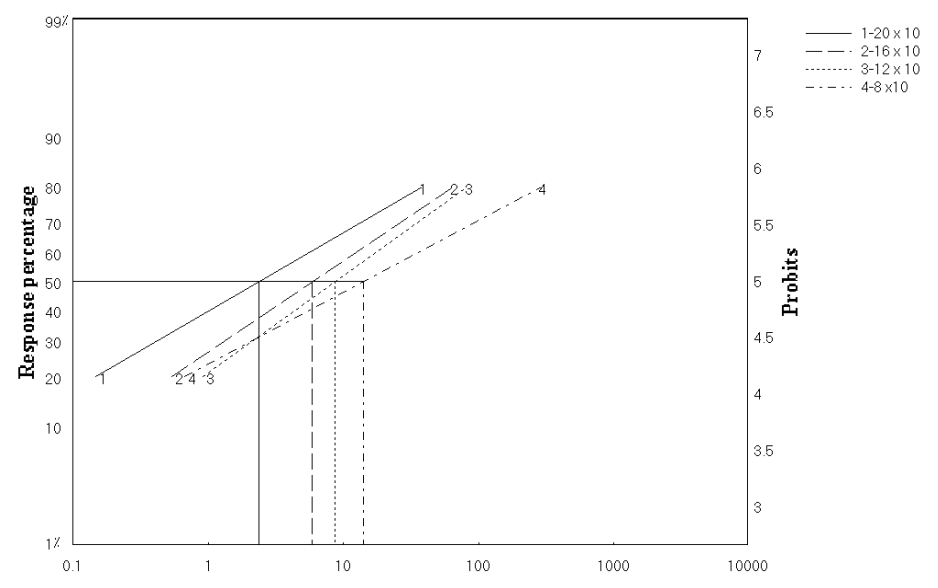

Fig. (7): Probit regression mortality time showing response of $2 \mathrm{rd}$ instar S. littoralis larvae at concentration of 8, 12,16 and $20 \times 104$ I.U of Diple 


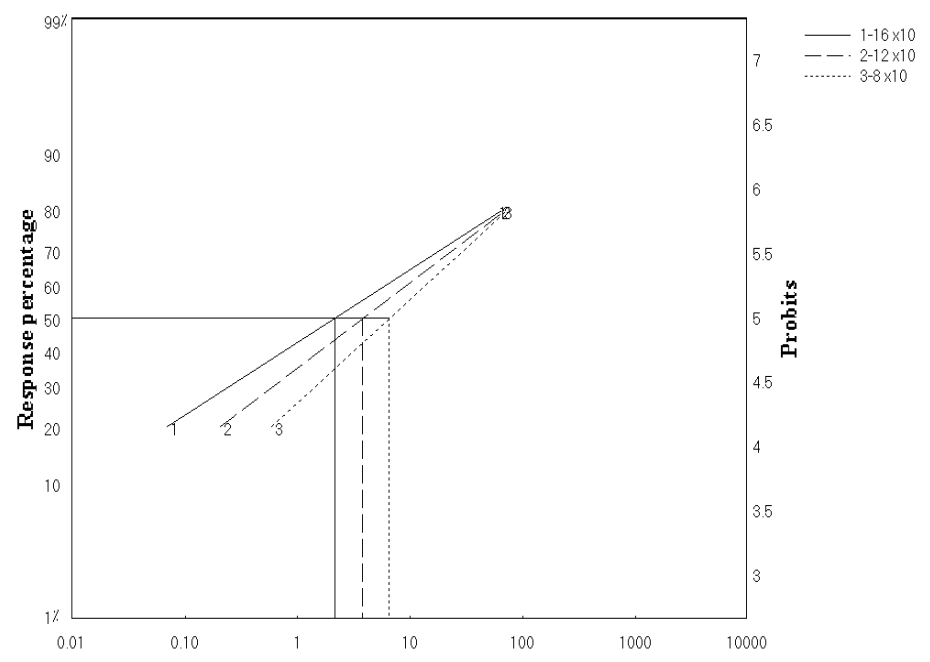

Fig. (8 ): Probit regression mortality time showing response of 2 rd instar S. littoralis larvae a concentration of 8,12 and $16 x$ 104 I.U of Diple2x $+0.5 \%$ amino $t$

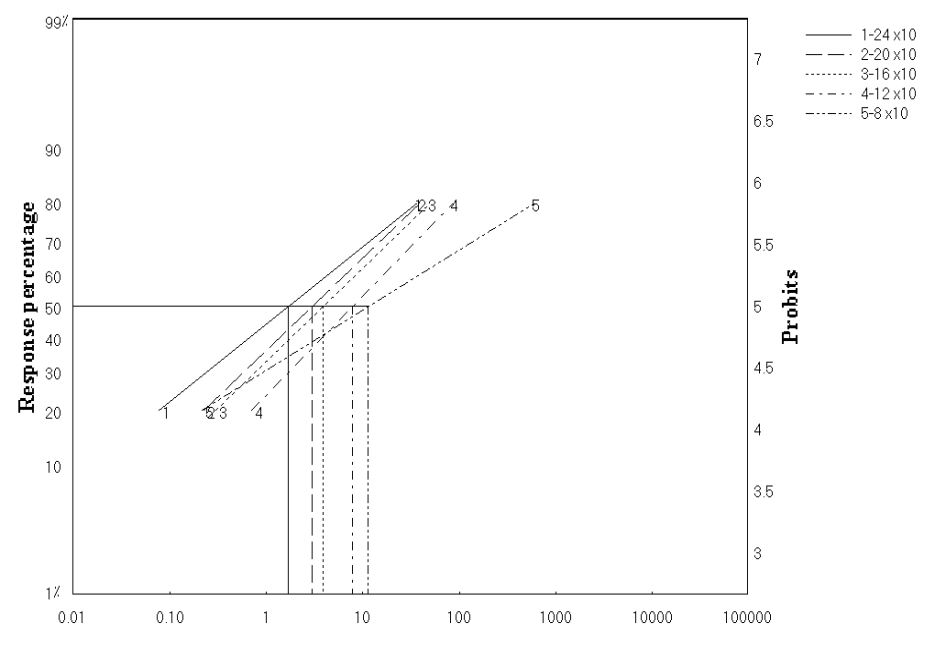

Fig. (9 ): Probit regression mortality time showing response of 2 rd instar S. littoralis larvae at concentration of 8, 12, 16, 20 and $24 \times 104$ I.U of Diple $+1 \%$ amino 


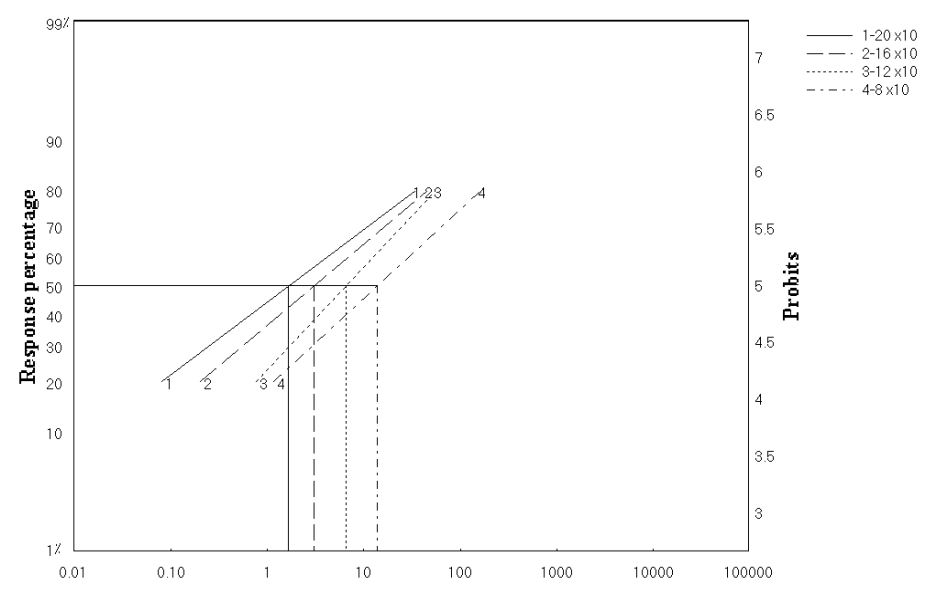

Fig. (10 ): Probit regression mortality time showing response of 2rd instar S. littoralis larvae at concentration of 8, 12, 16 and $20 \times 104$ I.U of Diple $+1.5 \%$ amino

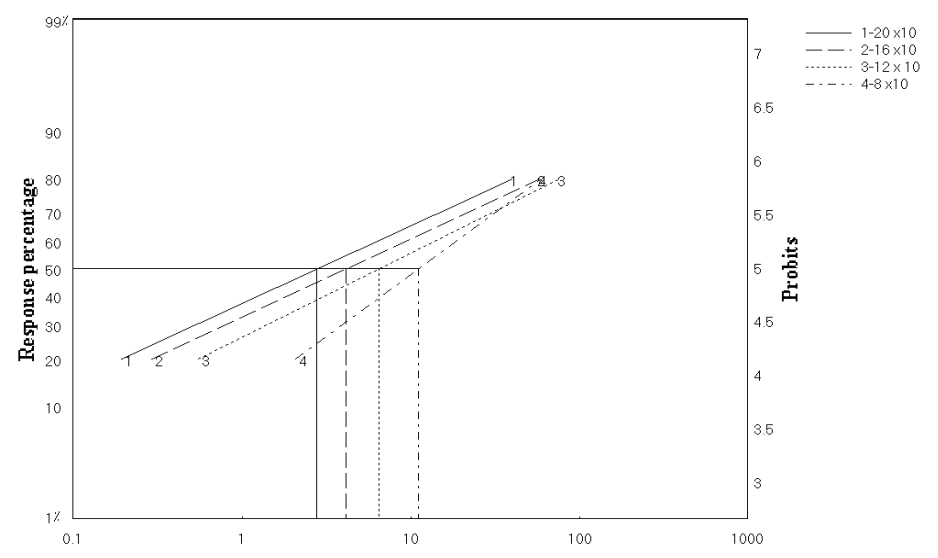

Fig. (11): Probit regression mortality time showing response of 2 rd instar S. littoralis larvae at concentration of 8, 12, 16 and $20 \times 104$ I.U of Diple $+2.5 \%$ amino

\section{CONCLUSION}

By comparing the effects of different treatments on the $\mathrm{LC}_{50}$ values, data presented in Table (2) revealed that, $\mathrm{LC}_{50}$ value of Dipel $2 \mathrm{x}+0.5 \%$ amino $\left(11.31 \times 10^{4}\right.$ I.U.) was the most effective one among all treatments. Also, these treatment led to shortened the values of $\mathrm{LT}_{50}(6.66,3.88$ and 2.18 
days for the used concentrations of 8,12 and $16 \times 10^{4}$ I.U., respectively) in comparison to other treatments (Table 3 ). The bioinsecticide Dipel $2 x$ could be recommended against $S$. littoralis which causes sever damage to wide variety of Egyptian crops. The bioinsecticide will be surely not harmful to the beneficial naturals, enemies especially parasitoids and predators, will also be safe to farm animals, and help in minimizing the environmental pollution by chemical insecticides.

\section{REFERENCES}

Amer, R A. M.; A. E Hatem;. and M.A. El-Sanady (2012): Microbial control of the tomato leaf-miner, Tuta absoluta (Povolny) (Lepidoptera: Gelechiidae) by biopesticides in relation to some biological parameters. Egypt. J. Biol. Pest Control. 22(2): 161-167.

Aranda, E.; J Sanchez,.; M.Peferoen,; L.Guereca, and A. Bravo (1996): Interactions of $B$. thuringiensis crystal proteins with the midgut epithelial cells of Spodoptera frugiperda. J. Invertebr. Pathol. 68(3): 203-212.

Ashraf M. A.(2013) : Bacillus thuringiensis Induces Cellular Stress in the Mosquito Vector ,Culex pipiens, Prior to Death. Pakistan J. Zool., 45(1):, 29-139, 2013

Atalla, F. A.; A.A. El-Zoghby and M.A. Eweis (2001): Susceptibility of the three lepdopterous pests, Sesamia cretica (Led), Spodoptera littoralis (Boisd) and Agrotis ipsilon (Hufn.)to the bacterial biocide Agerin.. (Egypt J. Biol. Pest Cont. 11(1): 45-49)

Azevedo, R. A.; A. P. Arrudavap; W. L. Turner, and L.E.A. PJ (1997): The biosynthesis and metabolism of the aspects derived amino acids in the higher plants. Phytochemistry $46,395-419$

Badawy, H. M. A. (2000): Efficacy and cytotoxic effect of bacterial insecticides on Spodoptera littoralis (Boisd.) and Phthorimaea operculella (Zeller). Bull ent. Soc. Egypt, Econ. Ser., 27: 41-53

Cartton, B. (1988): Development of genetically improved strains of Bacillus thuringiensis. In: Hedin, P., Menn, J. and R. Hollingrowth, (Eds), Biotechnology for crop Protection, American Chemical Society, Washington, D. C. PP. 260-279.

De Maagd, R. A.; Alejandra, and N. Crickmore (2001): How Bacillus thringiensis . has evolved specific toxins to colonize the insect world? Trends. Genet.17 (4): . . 193-199.

Ebaid, G. H. (2001): Studies on some corn borers parasitoids. Ph. D. Thesis, Fac., . . . Agric., Moshtohor Zagazig Univ. pp. 205

El-Husseini, M. M. ; E. A. Agamy; B. A. Mahmoud and R. F. Sallam (2012): Effects of Bacillus thringiensis Kurstaki on larvae of the spiny bollworm, Earias insulana (Boisd.) (Lepidoptera: Arctiidae). Egypt. J. Biol. Pest Control. 22(1): 67-71.

EL-Khawas, M.A. (2000): Integrated Control of Insect Pest on olive trees in Egypt with Emphasis on Biological Control. (Unpublished Ph. D. Thesis. Fac. of Sci., Cairo Univ., Egypt, 247 pp). 
El-Naggar, A. Z. (1998): Evaluation of certain foliars and micro- element in an integrated pest management, (IPM) program to control cotton bollworms, Msc Thesis, Faculty of Agriculture, Alexandria University, Egypt

El-Naggar, A.Z. (2009): Efficacy of some foliar fertilizers and alternative chemicals on the spiny bollworm, Earias insulana (Boisd.) larvae (Lepidoptera: Noctuidae). Alexandria J. Agric. Res., 54: 139-146

Finney,D ,J.(1971): Probit analysis $3^{\text {rd }}$ edition (Combridge Univ., pp33.

Gill, S. S.; E. A. Cowles, and P. V. Pietrantonio (1992): The mode of action of $B$. thuringiensis endotoxins. Annu. Rev. Entomol. 37, 61 5-636

Hedin, P. A.; W. P.; Williams, F. M Davis. and P. M. Buckley (1990): Role of amino acids, protein and fiber in leaf feeding resistance of corn to the fall armyworm. Journal of Chemical Ecology 16, 1977-1995

Lambert, B. and M. Peferoen . (1992): Insecticidal promise of Bacillus thuringiensis.Facts and mysteries about a successful biopesticide .Bioscience 42, 1 12-122.

Ibrahim, N. A. A. and M. N. A. Omar (2005): Expression of the insecticidal protein gene cryic of Bacillus thuringiensis in the plant- olonization nitrogen fixing bacteria. Egypt. J. Agric. Res. 83(1): 1-14.

Kares, E. A.; A. A. El-Morusy; M. A. Amina and M. R. El-Mandarawy (1992): Efficacy of a bioinsecticide (Bactospeine) on larvae of Artogeia rapae (L.) (Lepidoptera: Piridae). Egypt.J. Biol. Pest Control 2 (2): 123-130.

Kares, E. A; A. A. Hafez, F. F. Shalaby and G. H. Ebaid (2002): Evaluation of Trichogramma evanescens (Westwood) and Bacillus thuringiensis as control management tools of Ostrinia nubilalis (Lepidoptera: Pyralidae) in crn field at Qalubia Governorate. Egyptian J. of Biological Pest Control, 12(2), 71-77

Magdoff, F. and E. S. Hvan. (2000): Building soil for better crops. SARE, Washington DC

Mansour, E. S. (2001): New approaches for controlling the cotton leafworm and bollworms in relation to abundance of parasitoids and predators. Ph. D. Thesis, Fac. Agric., Moshtohor, Benha Branch, Zagazig Univ. Egypt, 262 pp.)

Mesbah, H.A.; M.M. Ibrahim; E.H. Tayeb; A.Z. El-Naggar and H.M. El-Nimr, (2000): Plant health, a new approach for the attainment of tolerant plants to pests infestation: Effect of fertilization and foliar application of nutritive elements on the infestation of cotton with bollworms. Adv. Agric. Res., 5: 1437-1454.

Moawad, G. M.; F. F. Shalaby; A. G. Metwally and M. M. El-Gemeiy (19821983): Laboratory pathagenecity tests with two commercial preparations of Bacillus thuringiensis (Berliner) on the first instar larvae of the spiny bollworm. Bull. Soc. ent. Egypte, 64: 137-141

Sogawa, K. and M. D. Pathak (1970): Mechanisms of brown plant hopper resistance to Mudgo variety of rice (Hemiptera, Delphacidae). Applied Entomology and Zology 5, 145-158.

Treshow, M., (1970): Environment and Plant Response. McGraw Hill Book Company, New York, USA., Pages: 422. 
Tsumuki, H.; K Kanehisa.; T Shiraga, T. and K. Kawada (1987): Characteristics of barley resistance to cereal aphids. Nutritional differences between barley strains. Nogaku Kenkyu 61, 149-159

Weibull, Jhw (1987): Free amino acids in the phloem sap from oats and barley resistant to Rhopalosiphum padi. Phytochemistry 27, 20692072.

تقييم فعالية Bacillus thuringiensis kurstaki منفردا أو مخلوطا بأحد الأحماض الأمينيه في مكافحة دودة ورق القطن

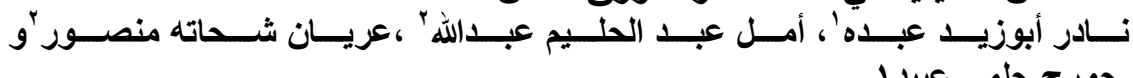

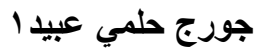

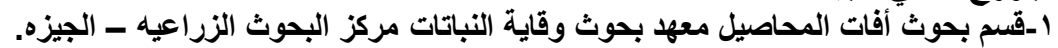

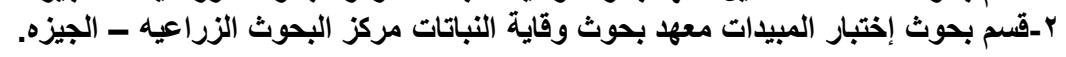

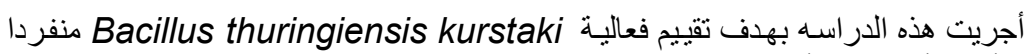

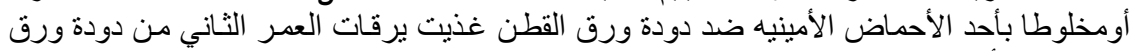

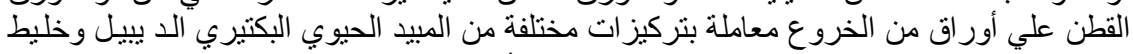

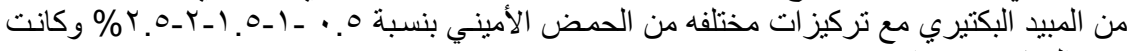

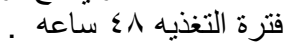

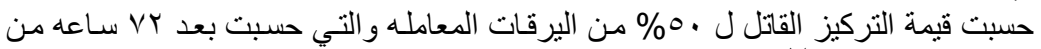

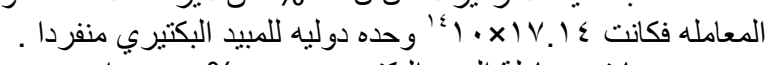

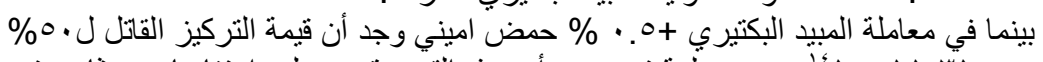

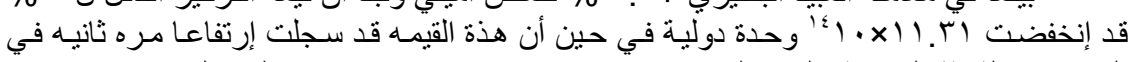

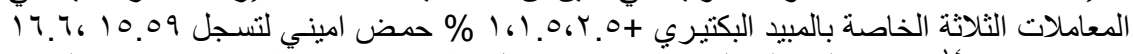

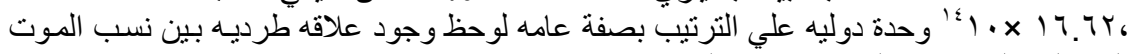

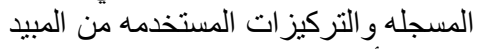

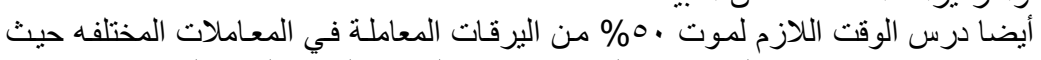

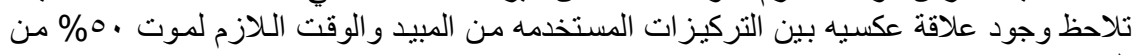

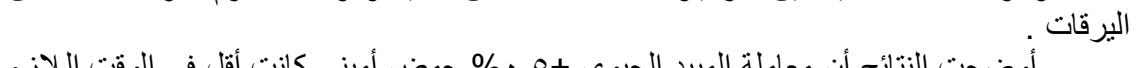

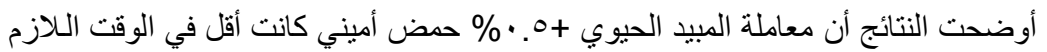

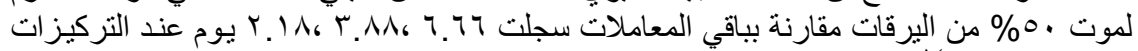
年 